\title{
SOFT POWER: POWER OF ATTRACTION OR CONFUSION?
}

\author{
Place Branding and Public Diplomacy (2008) 4:2, 147-158
}

\author{
Ying Fan \\ Brunel Business School \\ Brunel University \\ Uxbridge UB8 3PH \\ England \\ 44-1895-267239 \\ Ying.fan@brunel.ac.uk
}

\begin{abstract}
Despite its popularity soft power remains power of confusion. The paper examines the concept, with a special focus on the nature and sources of soft power. Nye's notion of soft power is largely ethnocentric and based on the assumption that there is a link between attractiveness and the ability to influence others in international relations. This poses two problems: Firstly, a country has many different actors. Some of them like the attraction and others don't. Whether the attraction will lead to the ability to influence the policy of the target country depends on which groups in that country find it attractive and how much control they have on policymaking. Secondly, policymaking at the state level is far more complicated than at the personal level; and has different dynamics that emphasise the rational considerations. This leaves little room for emotional elements thus significantly reducing the effect of soft power. Given the nature of soft power being uncontrollable and unpredictable, it would be impossible to wield soft power in any organised and coordinated fashion as Nye suggested. Furthermore, the relationship between two countries is shaped by many complex factors. It is ultimately decided by the geopolitics and strategic interests of nations, in which soft power may play only a limited role. The paper also discusses the link between soft power and nation branding as both concepts are concerned with a nation's influence on the world stage. Public diplomacy is a subset of nation branding that focuses on the political brand of a nation; whereas nation branding is about how a nation as whole to reshape the international opinions. A successful nation branding campaign will help create a more favourable and lasting image among the international audience thus further enhancing a country's soft power.
\end{abstract}

Key Words:

Soft power, cultural power, nation branding, public diplomacy, USA, China 


\section{Introduction}

Soft power, a term used in international relations and public diplomacy, was coined by Nye (1990) to describe co-optive power in contrast to hard power such as military actions. It refers to a country's ability to influence other countries' behaviour or "the ability to shape what others want", without using hard or coercive power, which is "the ability to change what others do" (Nye, 2004a). Nation branding, on the other hand, is a new area of interest in marketing that deals with a nation's effort to communicate to the people in other countries. Both concepts are concerned with the nation's influence on the international stage and its image in the mind of international stakeholders. The main purpose of this paper is to examine the concept of soft power, with a particular focus on the nature and sources of soft power. A detailed comparison between soft and hard power is presented; the limitations of soft power and its link to nation branding are also discussed.

\section{What is soft power?}

According to Collins English Dictionary (2003) the word of power has the following meanings:

- Ability or capability to do something;

- Political, financial, social etc. force or influence

- Control or dominion or a position of control, dominion or authority

Soft power, on the other hand, is a rather confusing concept. Nye does not give a simple definition. Instead, he describes soft power variously as (Nye, 2004a):

- ... the ability to shape the preferences of others (p5).

- ... the ability to attract, and attraction often leads to acquiescence (p6)

- ... the ability to get others to want the outcome you want because of your cultural or ideological appeal (p11)

- A country may obtain the outcomes it wants in world politics because other countries -admiring values, emulating its example, aspiring to its level of prosperity and openness - want to follow it (p5)

- ... a key element of leadership. The power to attract -to get others to want what you want, to frame the issues, to set the agenda (Nye, 2004b). 
A person is said to have power due to having one of the following attributes or a combination of them: status, authority, reputation, money, knowledge and beauty (Davies, 1991). Individuals such as Nelson Mandela or Mother Teresa have soft power because of their reputation. However, a nation is far more complicated than a person. It is unclear how attraction or attractiveness leads to power or influence in the context of a nation. Particularly it is important to consider:

- Who -

If a nation is said to have soft power, who actually possesses it: government, NGOs, commercial organisations or certain individuals? Does a country's geographic landscape, culture or customs also have soft power?

- What -

What consists of soft power - in what form and category? Or in other words, what are the sources of soft power?

- How relevant -

To whom is it soft power and to whom is it not?

Soft power may work on some people in a certain context, but not on all the people all the time.

Nye (2004a) also emphasises that the influence behind soft power is contingent on the pre-existing preferences of the other party, giving the example that to command an excited child to jump is no manifestation of power when he/she already enjoys jumping anyway. Consequently soft power is only meaningful in the context of a conflict of objectives, where persuasion and attraction may be employed to influence behaviour. The definition is mildly tautological if country A is said to wield soft power purely by setting an agenda of economic prosperity and success for country B to follow, since all countries desire this. The more significant question concerns the extent to which country B is willing to alter its perception of its objectives under the influence of country A, where previously it would have perceived A's actions to be detrimental to its own interests. 
Although Nye coined the term in 1990, the concept of soft power has its origin in the works of Hans J. Morgenthau, Klaus Knorr and Ray Cline. For example, Morgenthau (1967) identifies nine elements of national power, among which national character, national morale, the quality of diplomacy and the quality of government are closely associated with intangible sources of power, i.e. soft power. Similarly Carr (1964) writes that power over opinion is not less essential for political purposes than military and economic power, and has always been closely associated with them. These ideas have since been summarised and popularised in recent years by Nye (Gill and Huang, 2006). On the other hand, the management and psychology literature has long promoted the benefits of using referent (soft) power over coercive (hard) power (Cristo, 2005). According to Raven and French (1959), there are five bases of power: reward, coercive, legitimate, referent and expert. Soft power is a kind of referent power that is based on identification and attraction, and yields the greatest influence in relation to the other powers. The thinking behind the concept of soft power can be traced even back to more than two thousand of years. In ancient China, soft power was perceived stronger and more powerful than hard power, as suggested by proverbial wisdoms: to use soft and gentle means to overcome the hard and strong (以柔克刚 yi rou ke gang); and drips of water can penetrate a stone (滴水穿石 di shui chuan shi). Sun Tse (544-496BC), a military strategist of 2500 years ago, advocates winning a battle without a fight. The Chinese philosopher Confucius (551-479BC) believes that the ruler should win the allegiance of people with virtue (soft power) not by force (hard power). Similarly, Mencius (372-289BC) advocates rule in kingly way (王道 wang dao) rather than the tyrant way (霸道 $b a d a o$ ). The kingly way refers to governing by moral example whereas the tyrant way involves governing by brutal force (Wang, 2006). Lao Tze, a 
contemporary of Confucius, says in Tao Te Ching, "I know the benefit of wuwei (无为 do nothing); the softest can win the hardest. Invisible force can pass through the intangible."

\section{Sources of Soft Power}

Coupled with the problems in definition, it is equally confusing on what exactly constitutes soft power. Nye (1990) identifies three sources as: American culture, international laws and institutions, and American multinational corporations. But the list has changed to culture, political values and foreign policy: "the attractiveness of its culture, the appeal of its domestic political and social values, and the style and substance of its foreign policies" (Nye, 2004b). Nye did not offer any explanation why such changes were made. A close examination of these three key components of soft power shows some confusion. Firstly, policy, by definition, is the course or general plan of action adopted by state. A country's foreign policy itself is not a separate form of soft power but the mere manifestation of its hard power (political power in the case of military intervention; economic power in the case of aid or sanction). No matter how attractive the style of a country's foreign policies it cannot be separated from its substance which is an integral part of hard power. The US policies of the war on terror are good examples. Secondly, core values and domestic institutions are an essential part of any society's culture, not a separate source. Thus with only one component left, this makes the concept simpler and much clearer: soft power is cultural power.

Devoting a large proportion of his new book to the description of the sources of soft power in the US as well as in other countries, Nye (2004a) lists a wide range of various examples as the proxy measures of soft power: 
foreign immigrants

asylum applications

international students

tourists,

book sales and music sales

popular sports
Nobel prize winners

life expectancy

overseas aids

number of Internet hosts

spending on public diplomacy

With more examples added Nye seems to miss the point as to what soft power exactly is as the concept has been so stretched that the term comes to mean almost everything and therefore almost nothing (Hoagland, 2004). In all these examples given by Nye resources, sources (cause) and impact (effect) are mixed up. It is important to note sources and resources are not power per se but potential for power. The owners of these resources have to convert them into power. Four key factors must be in place for power conversion: capital, political structure, social capital and social structure (Treverton and Jones, 2005).

A key question still remains unanswered: whether the sources of soft power are universal or vary from one culture to another? Both China and India have rich cultural resources, but do they have the same type of soft power? If cultural power is soft power, why does a country like Egypt with a history of seven thousand years seem weaker compared with the US, founded only two hundred years ago? Clearly, culture per se is not soft power but sources of potential soft power. Whether a cultural asset can be converted into soft power depends on other factors.

\section{The nature of soft power}

Compared with hard power, soft power has a number of distinctive attributes. It is relative, intangible, and context based. Due to its diversified sources, soft power is difficult to measure and control.

Relative 
Soft power is a term relative in two senses. Soft and hard are related because they are both aspects of the ability to achieve one's purpose by affecting the behaviour of others. The distinction between them is one of degree (Nye, 2004b). Compared with military power, economic power is soft; but economic power (aid or sanction) is hard power compared with culture. Secondly, "all power depends on context - who relates to whom under what circumstances - but soft power depends more than hard power upon the existence of a willing interpreter and receivers (Nye, 2004b). A number of contextual variables affect the deployment of soft power by one country to another and the effect of such efforts on the latter, including geographic proximity, cultural similarity, historical relations and economic ties. Soft power is context specific, i.e. a form of soft power is relevant to only one specific country or a specific group in that country.

Intangible and Uncontrollable

Soft power in general is not controlled by the government or a single organisation. Soft power comes in various sources owned by non-state actors. However, there are exceptions. In a communist state such as China, as the party still controls almost all vital resources, particularly the media, the party/state does have a control over the use of soft power, either in the form of public diplomacy or state propaganda. Kurlantzick (2006) further classifies soft power into two types: high soft power targeted at elites; low soft power targeted at the broader public. As such, soft power is notoriously difficult to evaluate and measure. The impact of hard power is normally direct and immediate, straight and visible. In comparison, the effect of soft power is indirect and takes much longer to appear. It may take years to produce the desired outcome (Nye, 2004a, p99). 
The relevance of effectiveness of soft power depends on the perception of the target country audience on the host country; ultimately, they are the deciders of what is attractive to them and what is not. One reason behind the decline of American's soft power in Europe over the last decade is that since the end of Cold War, much of this soft power has lost its relevance as the old enemy of Soviet Union is no longer in existence. How can soft power be measured? A study by the Rand Corporation suggests that the best single indicator of a country's attractiveness (soft power) may be poll responses to the question "where would you like to live other than your own country" (Treverton and Jones, 2005).

There is one view that only the West or the countries with democratic institutions can produce soft power. For example, Raman (2005) claims that communist countries like China, despite its rich culture, have not been able to develop soft power. This is not true. No country has a monopoly on soft power. Any organisation, country and culture, can develop soft power - the question is not who can or cannot develop soft power but to whom it is soft power. To some, terrorist organisations such as the Taliban or AlQaeda have soft power. It is undeniable that whilst American has seen a decline in its soft power (Nye, 2004c), China's soft power is now on the rise, primarily in Southeast Asia, but also in Africa and Latin America (Kurlantzick, 2006; Nye, 2005; Business World, 2005). China's nation image in developing countries, particularly in Africa, is much more positive than in the west. For example, the "Beijing Consensus", a term coined by Ramo (2006) to refer to China's economic development model, is seen by many developing countries as a viable alternative to the western model. There are many published examples of Chinese soft power in Africa (Thompson, 2005). However, it is important to note that the influence and good relationships China has enjoyed in Africa are not the result of China's charm and friendship policies (soft power), but the product of four decades of "hard" investment by the Chinese government to cultivate such good 
will, i.e. investment in reputational capital, through an intended strategy to build relations through aid, trade, medical teams and education programmes since 1960s. The Chinese government recently waived one billion dollars of debt from some of the poorest countries in the continent (Pan, 2006).

On the world stage countries compete against each other for attention and attraction in the same fashion as commercial brands fight for market dominance. One country's gain in soft power, generally speaking, will lead to the loss of influence from another country. Nye (2005) regards the rise of China's soft power at America's expense as an urgent issue to be addressed. A recent example is 300 Confucius Institutes China has opened worldwide in the past few years to promote the Chinese language and culture. In an apparent attempt to counter Chinese influence, the Japanese government has recently decided to open a hundred schools abroad to teach the Japanese language.

The relationship between soft and hard power

The distinction between soft and hard power is a tricky one (for detailed comparisons see Table 1). Many would believe that soft power works better than hard power and could achieve what is unachievable by hard power. This may be just an illusion, as in reality soft power is much more difficult to use than hard power.

(insert Table 1 here)

Nye's view (2004a) on the relationship between the two forms of power is not very clear. On one hand, he says hard power and soft power are related because they are both aspects of the ability to achieve one's purpose by affecting the behaviour of others (p7). On the other, he argues soft power does not depend on hard power (p9). Is soft power usually independent of hard power as Nye believes or is it derivative of hard power (Huntington, 1996)? People will only admire your culture if you have the power to 
"coerce" them. In other words, the country with soft power needs at least some kind of resources (hard power) to communicate and promote its soft power. Soft power is nothing other than the "soft" face of hard power. Behind or beneath it is hard power. Soft power is merely a manifestation or presentation of hard power. There are different understandings about soft power, and particularly, about the relationship between soft and hard power:

1. Soft power is an integral part of hard power

2. Soft power is the "soft" or tactical part of power

3. Soft power is an extension of hard power

4. Soft power is linked with hard power, and can only work with the support of hard power

5. Soft power is independent of hard power

Some basic conditions must be in place before a country can wield soft power. It is important to distinguish potential and real soft power. A country with rich sources in soft power does not necessarily have the "power" at its disposal. In other words, the existence of soft power sources provides a deposit but the country needs to have the ability, means and other resources, quite often, hard resources, to tap into the deposit and convert this potential power into real power. Without hard power soft power can't work properly or not work at all. There is no country in the world that could exert significant soft power if it is in a dire economic situation. A country with soft power needs to find hard means - distribution channel or communication media, to "sell" it to the wide audience. Yet to extend soft power beyond the domain of influence requires the presence of some form of hard power, either to lend it credibility, or as a channel of distribution and communication. To a greater or lesser extent, many countries in the world possess the cultural potential to influence others but lack the hard presence in the geopolitical arena to communicate their agenda. 
Negative soft power

The negative soft power in many cases is the manifestation or fallout of hard power. The most negative power is coercion, which increases fear whilst decreasing attraction, and thus referent power (Cristo, 2005). Soft power, on the other hand, can make the use of hard power redundant. Whilst the US government's role in soft power is largely negative, corporations in the US have faired much better through Hollywood, Disney, Coca Cola and Nike. The key question is how a nation can exert both soft power and hard power in the way that the two forms of power work together to complement rather than undermine each other, or in Nye's (2004a) own words, avoiding a "self-cancelling effect". In the case of the Iraq War, the United States hard power and soft power have undermined each other and further damaged American's image in that region.

Power as relationship

Power can be regarded as a kind of relationship between two parties. Conventional wisdom suggests that there is inequality in such a relationship, i.e. the big strong party has power over the small or weak one; and the rich over the poor. The weak party is said to be powerless. Does the weak party have any strength or power over the strong one? According to Yin-Yang philosophy, there is a weakness in the strength and a strength in the weakness. The power equilibrium between the two parties does change over time. Far from being a constant force, soft power waxes and wanes based on world geopolitical events and relations between two countries and the target country's perception (Walch, 2004; Cristo, 2005).

\section{Limitations of soft power}

Despite its popularity the concept soft power remains a power of confusion. The definition is at best loose and vague. Because of such confusion it is not surprising that 
the concept has been misunderstood, misused and trivialised (Joffe, 2006a). Criticisms of soft power centre mainly around three aspects: definition, sources and limitations. There may be little or no relationship between the ubiquity of American culture and its actual influence. Hundreds of millions of people around the world wear, listen, eat, drink, watch and dance American, but they do not identify these accoutrements of their daily lives with American (Joffe, 2006b). To Purdy (2001) soft power is not a new reality, but a new word for the most efficient form of power. There are limits to what soft power could achieve. In a context dominated by hard power considerations soft power is meaningless (Blechman, 2004). The dark side of soft power is largely ignored by Nye. Excessive power, either hard or soft, may not be a good thing. In the affairs of nations, too much hard power ends up breeding not submission but resistance. Likewise, big soft power does not bend hearts; it twists minds in resentment and rage (Joffe, 2006b).

Nye's version of soft power that rests on affection and desire is too simplistic and unrealistic. Human feelings are complicated and quite often ambivalent, i.e. love and hate co-exist at the same time. Even within the same group, people may like some aspects of American values, but hate others. By the same token, soft power can also rest on fear (Cheow, 2002) or on both affection and fear depending on the context. Much of China' soft power in Southeast Asia testifies to this. Another example is provided by the mixed perception of the United States in China: people generally admire American technological superiority and super brands but detest its policies on Taiwan.

The whole concept of soft power -power of attraction- is based on the assumption that there is a link between attractiveness and the ability to influence others in international relations, i.e., such a power of attraction does have the ability to shape the preferences 
of others. This may be the case at the personal or individual level. It is questionable whether attraction power works at the nation level. Wang (2006) identifies two problems. Firstly, a country has many different actors. Some of them like the attraction and others don't. Whether the attraction will lead to the ability to influence the policy of the target country depends on which groups in that country find it attractive (e.g. the political elite, the general public or a marginal group); and how much control they have on policymaking. For example, soft power by Country A may have positive influence on the political elite but negative influence on the general public in Country B, or vice versa. Secondly, policymaking at the state level is far more complicated than at the personal level; and has different dynamics that emphasise the rational considerations. This leaves little room for emotional elements thus significantly reducing the effect of soft power. Even Nye (2004a) has to admit, what soft power can influence is not the policymaking itself but only the "environment for policy". Soft power may be counterproductive because societies react differently to American culture, the working of which are extremely complex, not least because of the diversity, as Fehrenbach and Poiger point out, in the "processes by which societies adopt, adapt, and reject American culture" (Opelz, 2004).

The relationship between countries is shaped by a variety of complicating factors; soft power may play only a limited role in such a relationship. But ultimately, it is decided by geopolitics and strategic interests of nations rather than the flimsy soft power, if the latter is found to be detrimental to the former. It is hard to imagine a country possessing great soft power without hard power to support it. It is no coincidence that the United States, as the world's only superpower, is in possession of enormous reserves of power, both hard and soft. Conversely, countries may share a similar agenda or cultural affinities, yet retain a sense of distance in their national relationships. The relationship 
between China and Japan is a case in point. Despite historical cultural links and recent strong economic ties, the animosity between the two neighbouring countries remains largely unchanged. Arguably, Japan, as a cultural superpower (McGray, 2002) in terms of cultural export, has more potential soft power resources than any other Asian country, but this has not resulted in proportionate perceived attractiveness in the region (Wang, 2006).

Nye's notion of soft power is largely ethnocentric and condescending as it is based on false assumptions of that American culture is superior and should be liked and adopted by other nations and that western values and culture that will continue to define the rules of the world (The Guardian, 2004). Western core values of democracy, liberty and consumerism, no matter how attractive or even admirable at first sight, may not necessarily be suitable (Hunter, 2006) or achievable in other countries. To many people around the world, the US self-perception of the superiority of American way of life is very much the root cause of troubles in the world. The predicament of the United States in places such as Afghanistan and Iraq shows a clear lesson that it is naïve to believe that West can export western-style democracy to other countries just like selling Coca Cola. Nye believes that anti-Americanism led to the decline of American's soft power. But in fact the opposite is true. Anti-Americanism is not just the result of the US foreign policies but a response to the ubiquity of its culture. The "over-success" of American's soft power has brewed resentment and increased anti-Americanism. This is evidenced by the fact that even in European countries - American's traditional allies - a majority of people regard the spread of American culture as a bad thing (The Pew Research Centre, 2002). Because of this confusion over cause and effect, the solution offered by Nye to enhance US soft power is in fact a part of the cause of the problem. 
Power is a double-edged sword and thus cuts two ways. Power has always given rise to the dichotomy of attraction and repulsion, whether soft or hard (Opelz, 2004). Soft power too can breed resentment and bitterness. Even Nye (2004b) himself admits that no country likes to feel manipulated, even by soft power. Power is power, no matter if it is soft or hard, there is no difference in terms of its utility: influencing people's mind and behaviour to achieve one's objectives. Soft power is still power and it can still make enemies (Joffe, 2006a). The instrumental nature of power can lead to feelings of manipulation, and the perception of ubiquitous and invasive cultural imperialism is sufficient to create antagonism or even a backlash. The dialectic of soft power presents an ambiguous juxtaposition of outcomes which disqualifies soft power from sustaining any system or structure on its own. Rather, one can envisage a value ideology emerging from the successful rise of hard power institutions that proposes an alluring prospect for emulation, which forms the foundation for soft power.

To sum up there is a big paradox in the concept of soft power. As soft power rests on attraction, the "power" lies not in the hand of the party who possesses it, but in the response and reaction of the party who receives it. Because of this unique nature of soft power, a nation's soft power over another nation is not a factor that can be exploited purposely in any coherent way (Blechman, 2005). Next, given the nature of the concept - intangible, uncontrollable and unpredictable, it would be impossible to wield soft power in an organised and coordinated fashion as Nye (2005) suggested. Finally, human feelings such as attraction and affection can be fickle, so soft power based on this is difficult to sustain. This explains why policy makers have realised the increasing importance of soft power but found it difficult to apply (Treverton and Jones, 2006). 


\section{Soft Power and Nation Branding}

Many countries in the world today suffer from image problems which are caused internally by the dramatic changes taking place in the political-economic-social landscapes, and externally due to the effect of outdated stereotypes. Despite globalisation, global travel and the advancement of technology, particularly the Internet, it is surprising that huge gaps and barriers still exist in the understanding between countries and cultures. Developing countries and those in the transitional economies suffer from little brand awareness or negative perceptions. These countries may have rich sources for soft power, but they do not have adequate resources (financial resources and knowhow) to turn this potential into reality. Governments around the world have increasingly recognised the need to tell the story of their nation to the target international audience, not in simplistic propaganda, but with subtlety and sensitivity (Pilon, 2005). This practice has been termed as country branding or nation (Olins, 2002; Anholt, 1998). Countries have practiced nation branding for ages. For example, the French in the Seventeen Century went to much greater lengths in remoulding their country's image abroad than other European countries, and they put enormous efforts into managing their country's reputation, seeing it as one of the principal sources of a nation's power (Melissen, 2005).

As a subject for academic research, nation branding is a relatively new area (Fan, 2006; Papadopoulos and Heslop, 2002). There is still no agreement about what the concept is and whether a nation can be branded (Aldersey-Walliam, 1998; Gudjonssson, 2005). To some, it is simply another term for country of origin effect or place marketing (Kotler, 2002). In a globalised world countries must manage and control their branding if they are to compete effectively with other countries. Active repositioning of a country through branding can give a country competitive advantage over other countries 
(Gilmore, 2002) and bring the benefits of tourism and foreign investment. To others, it refers to a consistent and all-embracing national brand strategy which determines the most realistic, most competitive and most compelling strategic vision for the country, and ensures that this vision is supported, reinforced, and enriched by every act of communication between the country and the rest of the world (Anholt, 1998). In essence, nation branding concerns the application of branding and marketing communications techniques to reshape the international opinion of a country. Nation branding is in fact a cross-cultural communication process which very much resembles the advertising process: awareness -attraction- preference. The crucial question is what messages are sent under what circumstances, who received them and how the messages are interpreted.

Although there has been a steady growth in the interests and publications around the topic in the last five years (Dinnie, 2007), nation branding still faces serious challenges from outright objection to cynical scepticism among the public (Olins, 2002; Kabn, 2006). The public scepticism on the use of the term branding is such deep-rooted that Anholt (2007), one of the prominent advocates of nation branding, has recently re-brand the concept as "competitive identity" (CI), which is described as a new model for enhancing national competitiveness using both public diplomacy and brand management.

The world is increasingly like a gigantic stage on which nations are competing against each other for attention and affection. Nation branding holds the key to win this global "beauty contest". There is no substitute for consciously developing a nation's brand (Olins, 2005). With economic development it is inevitable for countries to look at their outdated images by re-branding the nation. South Korea and Spain did in the 1980s and 
1990s and now China is trying to do the same with Beijing Olympics 2008 and Shanghai World Expo 2010. The rise of China's soft power along with its economic power and military power has been greeted differently. While the developing countries welcome China's influence (Pew, 2007), many in the west see it as China threat (Nye, 2005), or Sinoization" of Asia (Treverton and Jones, 2005).

Nation branding can be an important tool in the development of a nation's soft power. A successful nation branding campaign will help create a more favourable image among the international audience thus further enhancing a country's soft power. Branding a nation is much more than just finding a catching slogan or window-dressing but requires the study of a nation's soft power sources in order to exploit them effectively to promote the national image. Nation branding has been practiced in two different ways: one is closely related to place branding or destination marketing with specific commercial purposes (promoting tourism or inward investment) - Branding New Zealand being a notable example (www.newzealandthinking.com). Another focuses mainly on the political or diplomatic dimension: the US State Department has an under-secretary for public diplomacy with a mission of "turning around antiAmerican sentiment in the world" (Los Angeles Times, 2005). There are three key components in nation branding, or in other words, a nation's brand consists of three sub-brands: political brand, economic brand and cultural brand (Fan, 2008a). These three brands are intertwined and need to work in synergy to achieve the same goal of promoting a nation's image.

Nation branding should be distinguished from a nation brand as there is not necessarily a direct link between the two. A nation's 'brand' exists with or without any conscious efforts in nation branding, as each country has a current image to its international 
audience, be it strong or weak, clear or vague (Fan, 2006:12). A nation brand can be defined as the total sum of all perceptions of a nation in the mind of international stakeholders which may contain some of the following elements: people, place, culture/language, history, food, fashion, famous faces (celebrities), global brands etc. Clearly these are also the sources of potential soft power identified earlier in the paper. Unlike a commercial brand that has a single identifiable owner, a nation brand is not owned by the nation's government or people, but by any organization that wishes to exploit the nation's image or to create a nation brand for commercial advantage.

To transform soft power from a potential source into real power, a number of issues need to be addressed. The competitiveness of cultural industry and necessary media infrastructure provide the stage for the nation branding show. China is a case in point. With almost everything made in China, the country has huge trade surplus with many countries. However, China suffers a big cultural deficit in terms of cultural exports. "While we are great in cultural resources, we are not strong in cultural industries", says an article in the influential People's Daily(2005). Secondly, whether a unique cultural product from a country can serve as a form of soft power depends on how to internationalise the product. Shaolin Kungfu is a case in point. While Tae kwon Do from Korea has become one of the most widely practiced martial arts in the world and an Olympic event, Shaolin remains still largely unknown outside China.

\section{CONCLUSION}

Soft power is a form of power based on a country's cultural resources. It is intangible, relative, context-based, and controlled largely by non-state actors. The relevance and ultimate effectiveness of soft power depends on the perception and response of its target audience. Soft power is based on the central assumption "to get others to want what you 
want" (Nye, 2004b). This remains untested and it is not clear how this can be achieved in reality.

Soft power is still power, and wielding is a menacing word. Two countries in this power relationship should get mutual benefits otherwise such a relationship won't last. It is important for a country to know how to set limits to its power, as suggested by Niebuhr (1932). He warns of the perils of American power and believes that US security lies in "reducing our power to a minimum". It would be interesting to find out whether it is possible for a country to achieve its objective without using any power or using minimum power.

With enormous soft power in the form of global brands, multinational companies can play a key role in promoting a nation's image. In the absence of a coherent nation branding campaign, corporate brands can in fact act as the ambassador for a country's image in the world, and are a tangible manifestation of a country's soft power. In many cases they are seen as the de facto brand of a nation, i.e. they are the nation's brand. Japanese prime minister is quoted as saying that Sony and Matsushita (Panasonic) are the left and right faces of Japan (Fan, 2008b). Such brands emerge from the stability and success of a country's political and economic institutions - the foundation of its hard power - and consequently contribute to nation branding in aggregate. A good cultural product and a number of successful global brands are vital in creating a long lasting impact in nation branding.

Soft power and nation branding are two closely linked concepts. Nation branding concerns how a nation as a whole presents and represents itself to other nations (Anholt, 2006), whereas public diplomacy is a subset of nation branding that focuses on 
the political brand of a nation. Compared with Nye's notion of soft power through public diplomacy, nation branding provides a more focused, culturally unbiased and more useful approach to creating international influence in the world.

\section{References}

Aldersey-Williams, H. (1998) “Cool Britannia's big chill”, New Statesman, April 10, 12-13

Anholt, S. (1998) "Nation-brands of the twenty-first century", Journal of Brand

Management, 5:6, 395-406

Anholt, S. (2006) "Public diplomacy and place branding: where is the link?" Place Branding, 2:4, 1-5

Anholt, S. (2007) Competitive identity: The new brand management for nations, cities and regions, Palgrave Macmillan, Basingstoke

Blechman, B. M., (2004) Book review, "Soft power: the means to success in world politics", Political Science Quarterly, 680-681

Business World, (2005) The rising "soft power" of China and India", 30 May

Carr, E. H., (1964, first edition 1939) the Twenty years' crisis, 1919-1939: An introduction to the study of international relations, Harper\&Row, NY

Cheow, E. (2002) All things 'Chinese' take on the world, The Straits Times, 11 Sept.

Collin's English Dictionary, (2003) $6^{\text {th }}$ ed. Collins Publishers, London

Cristo, D. A. (2005) Book review, "Soft power: the means to success in world politics", American Economist, 49:2, p99

Davies, P, (1991) Status: What it is and how to achieve it, Piatkus, London

Fan, Ying, (2008a) "Key perspectives in nation image: a conceptual framework for nation branding", Working paper, Brunel University Research Archive (BURA), available at http://bura.brunel.ac.uk/items-by-author?author=Fan\%2C+Y\&order=date

Fan, Ying, (2008b) "Country of origin, branding strategy and internationalisation: the case of Chinese piano companies", in press Journal of Chinese Economic and Business Studies

Fan, Ying, (2006) Nation branding: what is being branded? Journal of Vacation Marketing, 12:1, 5-14

Dinnie, K. (2007) Nation branding: Concepts, issues, practice, Butterworth Heinemann Gill, B. and Huang, Y. (2006) Sources and Limits of Chinese 'Soft Power", Survival, 48:2 Summer, pp. 17-36, p. 31

Gilmore, F. (2002) "A country -can it be repositioned? Spain -the successful story of country branding", Journal of Brand Management, 9:4/5, 281-293

Gudjonsson, H. (2005) "Nation branding", Place Branding, 1:3, 283-298

Hoagland, J. (2004) Elasticity, The New Republic, May 17 p30-34

Hunter, A. (2006) China: soft power and cultural influence, Working paper, Centre for Peace and Reconciliation Studies, University of Coventry

Huntington, S. (1996) The clash of civilizations and the remaking of world order, p92, Simon\&Schuster, NY

Joffe, J. (2006a) "The peril o soft power", NYT Magazine, May 15

Joffe, J. (2006b) "America, the Ubiquitous-When one nation dominates the world, its power breeds unease, resentment, and denigration", available at:

http://www.swarthmore.edu/bulletin/index.php?id=457 
Kabn, J. (2006) "A brand-new approach", Foreign Policy, Nov./Dec. available at http://www.foreignpolicy.com/story/cms.php?story_id=3608

Kotler, P. (2002) "Country as brand, product, and beyond: a place marketing and brand management perspective", Journal of Brand Management, 9:4-5, 249-261

Kurlantzick, J. (2006) China's charm: implications of Chinese soft power, Policy Brief, no. 47 June, Carnegie Endowment for International Peace

Los Angeles Times, (2005), 23 July

McGray, D. (2002) Japan's gross national cool, Foreign Policy, May/June

Melissen, J. (2005) Wielding soft power, the new public diplomacy, Clingendael Diplomacy Papers, No.2, Netherlands Institute of International Relations Clingendael

Morgenthau, H, J, (1967) Politics among Nations: the struggle for power and peace, p158, Alfred A Knopf, NY

Niebuhr, Reinhold, (1932) Moral Man and Immoral Society. New York: HarperCollins

Nye, J.S. (1990) Bound to Lead: The Changing Nature of American Power, Basic Books, NY

Nye, J. S. (2004a) Soft Power: the means to success in world politics, p7-8, Public Affairs, NY

Nye, J. S. (2004b) The benefit of soft power, HBS Working Knowledge

Nye, J. S. (2004c) The decline of America's soft power", Foreign Affairs, May/June

Nye, J. S. (2005) The rise of China's soft power, the Wall Street Journal Asia, 29 Dec.

Olins W. (2002) "Branding the nation - the historical context", Journal of Brand

Management, 9:4-5, 241-248

Olins, W. (2005) "Nation branding in Europe", available at www.saffron-

consultants.com/Common/Downloads/Nationbranding.pdf

Opelz, H. (2004) Anti-Americanism and the paradox of soft power, Article \#122, www.thetalent.org/Indice/Show/Aritcoli-HTML/main.php?show=122

Pan, E. (2006) China's soft power initiative, Council on Foreign Relations, www.cfr.org/publication/10715

Papadopoulos, N. and Heslop L. (2002) "Country equity and country branding:

problems and prospects", Journal of Brand Management, 9:4-5 294-314

Pew, (2007) Global Attitude Project, http://pewglobal.org/

Pilon, J. C. (2005) Book review, "Soft power: the means to success in world politics",

Mediterranean Quarterly, Spring, 125-131

Purdy, J., (2001) Universal nation, the American Prospect, Nov.

Raman, B. (2005) Chinese quest for soft power, Paper no.2209, South Asia Analysis Group

Ramo, J. (2006) Brand China, Foreign Policy Centre, London

Raven, B. and French, J. R. (1959) The bases of social power, in Studies in Social Power, edited by Cartwright, D. P. MI: Institute for Social Research, University of Michigan

The Guardian, (2004) Journalism: Chinese soft power, 11 September

The People's Daily, (2005) Overseas edition, 23 Nov.

The Pew Research Centre, (2002) What the world thinks in 2002, the Pew Research Centre for the People and the Press, http://people-press.org/

Thompson, D. (2005) China's soft power in Africa: from the 'Beijing consensus' to Health diplomacy, www.asiamedia.ucla.edu/article.asp?parentid=32003

Treverton, G. F. and Jones, S. G. (2005) Measuring national power, Conference Proceedings, the Rand Corporation, available from www.rand.org

Walch, R. (2004) Book review: "Soft power: the means to success in world politics", America, August 2-9, p23 
Wang, J. (2006) "Chinese conception of soft power and its policy implications", International Conference on "China in the International Order", Spet. Nottingham University

Table 1 Comparison of Hard and Soft Power

\begin{tabular}{|l|l|}
\hline Hard Power & Soft Power \\
\hline $\begin{array}{l}\text { Ability to change others' position by } \\
\text { force or inducement }\end{array}$ & $\begin{array}{l}\text { Ability to shape the preferences of } \\
\text { Others by attraction }\end{array}$ \\
\hline Military and economic power & Cultural power \\
\hline Coercion, force & Co-option, influence \\
\hline Absolute & Relative, context based \\
\hline $\begin{array}{l}\text { Tangible, easy to measure, predictable } \\
\text { to certain degree }\end{array}$ & $\begin{array}{l}\text { Intangible, hard to measure, } \\
\text { unpredictable }\end{array}$ \\
\hline Ownership specified & Unspecified, multiple sources \\
\hline Controlled by State or organisations & Mostly non-state actors, uncontrollable \\
\hline External, action, push & Internal, reaction/response, pull \\
\hline Direct, short term, immediate effect & Indirect, long term, delayed effect \\
\hline Manifested in foreign policies & Communicated via nation branding \\
\hline
\end{tabular}

